rp0399a.doc

\title{
The Nature of Innovation Market Failure and the Design of Public Support for Private Innovation
}

\author{
March 19991 \\ Stephen Martin \\ Centre for Industrial Economics \\ University of Copenhagen \\ 1455 Copenhagen K \\ Denmark \\ smart@econ.ku.dk \\ John T. Scott \\ Department of Economics \\ Dartmouth College \\ Hanover, NH 03755 \\ U.S.A. \\ John.T.Scott@Dartmouth.Edu
}

JEL codes: O31, O38

Keywords: innovation, technological change, innovation policy

Abstract: We relate the sources of innovation market failure to the dominant mode of sectoral innovation and outline mechanisms for public support of innovation that target specific sources of innovation market failure.

1 We thank William L. Baldwin for extensive comments and are also grateful to anonymous referees for advice. Earlier versions of some of the materials used in this paper appeared in Link and Scott (1998b), Martin and Scott (January 1998), and Scott (STI Review, 1998b). Responsibility for errors is our own. 


\section{Contents}

$\begin{array}{ll}\text { I. Introduction } & 2\end{array}$

II. A Typology of Innovation Market Failures and Intervention Models 5

$\begin{array}{ll}\text { III. Innovating Input Suppliers } & 7\end{array}$

$\begin{array}{ll}\text { IV. Innovating Input Users } & 12\end{array}$

V. Complex Systems Innovation 14

$\begin{array}{ll}\text { VI. High Science-Content Technology Industries } & 16\end{array}$

$\begin{array}{lr}\text { VII. Conclusions } & 18\end{array}$

$\begin{array}{ll}\text { VIII. References } & 21\end{array}$ 


\section{Introduction}

The analysis of innovation in a free enterprise system was long framed by the work of Joseph Schumpeter, who at different stages in his career entertained two very different views of the relationship between market structure and technological performance.

In The Theory of Economic Development (1934) Schumpeter envisioned technological advance as the consequence of a never-ending cycle of entry by innovative firms, commercial application of new products or processes, displacement of incumbents, followed by entry of a new generation of innovative firms. This model of innovative activity suggests that ease of entry will promote innovation and that small- and medium-sized enterprises (SMEs) will most often be the vehicles of technological advance. The early Schumpeter did not rule out innovation by established firms, but he thought it an exceptional phenomenon (1934, p. 136):

The same is true if a new enterprise is started by a producer in the same industry and is connected with his previous production. This is by no means the rule; new enterprises are mostly founded by new men and the old businesses sink into insignificance.

It is the later Schumpeter, the Schumpeter of Capitalism, Socialism, and Democracy, who maintains a higher profile in policy discussions. Here Schumpeter conceived of technological progress as emanating from the industrial research laboratories of large firms that enjoyed positions of static market power. He argued that such firms would use their economic profits to finance risky, large-scale R\&D activity that would simultaneously leave society better off, in a dynamic sense, and 
allow the firms to maintain positions of static product-market dominance (1942, p. $82):^{2}$

As soon as we go into details and inquire into the individual items in which progress was most conspicuous, the trail leads not to the doors of those firms that work under conditions of comparatively free competition but precisely to the doors of the large concerns . . . and a shocking suspicion dawns upon us that big business may have had more to do with creating that standard of life than with keeping it down.

This second view suggests that the rate of technological advance will be greater where a few large firms dominate product markets. Such firms would be better able to finance investment in innovation, could take advantage of such economies of scale as might exist in the $\mathrm{R} \& \mathrm{D}$ process, and, because they typically produce a diversified range of products, would be more likely to find commercially viable applications for new technological developments. He also viewed risk as an inherent aspect of research, development, and commercialization, and saw market power as a way to provide "insurance" against such risk. ${ }^{3}$

The early stages of the modern economic literature on research and development were largely devoted to sorting out the implications of these two divergent positions. While this debate remains a lively one ${ }^{4}$ the resulting literature has produced the recognition that the level of investment in research and development is likely to be too low, from a social point of view, whether market structure is nearly atomistic, a highly concentrated oligopoly, or something in between. Limited appropriability, financial market failure, external benefits to the production of knowledge, and other factors suggest that strict reliance on a market system will result

2 Kamien and Schwartz (1982) emphasize the contribution of Galbraith (1952) to establishing the large-firm vision of innovation that is popularly associated with the name of Schumpeter.

${ }^{3}$ See Baldwin and Scott (1987, pp. 2-3).

${ }^{4}$ See, in particular, Fisher and Temin (1973) and Kohn and Scott (1982). 
in underinvestment in innovation, relative to the socially desirable level..$^{5}$ This creates a prima facie case in favor of public intervention to promote innovative activity.

Given the large number of policy instruments available to promote private investment in R\&D - competition policy and tax policy, as well as subsidies and actual R\&D carried out by public research units — the question of the design of policy instruments to promote $\mathrm{R} \& \mathrm{D}$ has moved to center stage.

It is instructive to consider the advice economists offer for the design of innovation policy in light of the evolution of industrial economics itself.

At the start of the 1970s, industrial economics was organized around the structure-conduct-performance paradigm. From a current perspective, perhaps the most striking characteristic of the S-C-P paradigm was its self-avowed generality. The basic unit of observation was the industry. An industry could be described in terms of its characteristics. Given information about industry characteristics, predictions could be made about industry performance. Suggestions for the promotion of R\&D were similarly general: across-the-board tax breaks for firms that invested in $\mathrm{R} \& \mathrm{D}$, for example, or general increases in patent length or breadth.

The modern game-theoretic approach makes no such claims to generality. Today the organizing framework of industrial economics is a collection of highly specific game-theoretic models, each tailored to fit a market that is described in terms of detailed assumptions about strategic variables, sequences of moves, information sets, and solution concepts.

5 The rent-seeking literature (Fudenberg and Tirole, 1987; Anderson et al., 1997) suggests at least the possibility of overinvestment in innovation: competing rivals, each seeking a post-innovation competitive advantage, may spend more in total than the innovation justifies, from society's point of view. Baldwin and Scott (1987) characterize this as "the overbidding problem" as contrasted with the "appropriability 
To take full advantage of the insights offered by modern industrial economics, policy advice that is informed by economic analysis should be similarly specific, taking explicit account of features of the real world that can often be assumed away in theoretical discussions. We take as our starting point the consensus of the literature 6 that reliance on market processes alone will result in underinvestment in research and development, from a social point of view. Rather than debate whether innovation is promoted in general by unconcentrated market structures and ease of entry or by enduring dominant positions of leading firms, we argue that R\&D policy should draw on the received catalog of specific sources of underinvestment in innovation to inform the design of public policy.

II. A Typology of Innovation Failure and Intervention Models

The forces leading to private underinvestment in innovation differ from sector to sector across the economy, and policy design should take these differences into account. The contribution of public resources can take many forms, and we put forward a classification of promotional measures that aim to match public action to sectoral sources of innovation market failure.

Table 1 outlines a typology of innovation modes and sectoral innovation failures. ${ }^{7}$ Any such classification must of necessity be both crude and approximate. The categories in the table are not mutually exclusive, and the policy measures cited in

problem." Empirical evidence (for example, estimated rates of return to investment in R\&D) suggests that on balance it is underinvestment that is observed in practice.

6 Perhaps one of the few points on which there is consensus.

7 This is based on Pavitt (1984) and influenced by Dosi (1988), Nelson and Rosenberg (1993), and Tassey (1997). 
the table are indicative rather than exhaustive. In particular, we assume an antitrust regime designed to promote vigorous product-market competition. ${ }^{8}$

\begin{tabular}{|l|l|l|l|}
\hline $\begin{array}{l}\text { Main mode of } \\
\text { innovation }\end{array}$ & $\begin{array}{l}\text { Sources of Sectoral } \\
\text { Innovation Failure }\end{array}$ & Typical sectors & Policy instrument \\
\hline $\begin{array}{l}\text { Development of inputs } \\
\text { for using industries }\end{array}$ & $\begin{array}{l}\text { Financial market trans- } \\
\text { actions costs facing } \\
\text { SMEs; risk associated } \\
\text { with standards for new } \\
\text { technology; limited } \\
\text { appropriability of } \\
\text { generic technologies }\end{array}$ & $\begin{array}{l}\text { Software, equipment, } \\
\text { instruments }\end{array}$ & $\begin{array}{l}\text { Support for venture } \\
\text { capital markets; } \\
\text { bridging institutions to } \\
\text { facilitate standards } \\
\text { adoption }\end{array}$ \\
\hline $\begin{array}{l}\text { Application of inputs } \\
\text { inveloped in supplying }\end{array}$ & $\begin{array}{l}\text { Small firm size, large } \\
\text { external benefits; } \\
\text { induites }\end{array}$ & $\begin{array}{l}\text { Agriculture, light } \\
\text { industry }\end{array}$ & $\begin{array}{l}\text { Low-tech bridging } \\
\text { institutions (extension } \\
\text { services) to facilitate } \\
\text { technology transfer }\end{array}$ \\
\hline $\begin{array}{l}\text { Development of } \\
\text { complex systems }\end{array}$ & $\begin{array}{l}\text { High cost, risk, limited } \\
\text { appropriability (partic- } \\
\text { ularly for infrastructure } \\
\text { technology) }\end{array}$ & $\begin{array}{l}\text { Aerospace, electrical \& } \\
\text { electronics technology, } \\
\text { telecom/computer tech- } \\
\text { nologies, semiconduc- } \\
\text { tors }\end{array}$ & $\begin{array}{l}\text { R\&D cooperation, } \\
\text { subsidies; bridging } \\
\text { institutions to facilitate } \\
\text { development of infra- } \\
\text { structure technology }\end{array}$ \\
\hline $\begin{array}{l}\text { Applications of high- } \\
\text { science-content } \\
\text { technology }\end{array}$ & $\begin{array}{l}\text { Knowledge base } \\
\text { originates outside } \\
\text { commercial sector; } \\
\text { creators may not recog- } \\
\text { nize potential applica- } \\
\text { tions or effectively } \\
\text { communicate new } \\
\text { developments to } \\
\text { potential users }\end{array}$ & $\begin{array}{l}\text { Biotechnology, } \\
\text { shemistry, materials } \\
\text { science, } \\
\text { pharmaceuticals }\end{array}$ & $\begin{array}{l}\text { High-tech bridging } \\
\text { institutions to facilitate } \\
\text { diffusion of advances in } \\
\text { basic research }\end{array}$ \\
\hline
\end{tabular}

Table 1: Innovation Modes, Sources of Sectoral Innovation Failure, and Policy Responses

Markets differ in terms of the mixture of basic and applied knowledge that contributes to their knowledge base, in the degree of appropriability of technology, in the extent to which commercially applicable knowledge is tacit, hence less likely to

8 See, generally, Nelson (1982, pp. 474-6). An antitrust regime that frowns on the erection of artificial barriers to entry will promote innovation by new firms. In this regard, see Baker (1998), who suggests that the monopolization rulings in Aspen Skiing and Kodak will encourage fringe firm innovation in some industries, by increasing the expected payoff to such innovation, without reducing the incentives for dominant firms to innovate. Martin (1998a) shows that if successful innovation improves static market performance, a strict deterrence-based product-market competition policy reduces expected profit before and after innovation, but reduces pre-innovation profit relatively more, increasing private incentives to invest in innovation. 
leak out, and in the importance of complementary assets to the commercialization of knowledge. Table 1 carves what is really a continuous range of variation along these dimensions into four broad categories, based on the main mode of innovation in each group of industries. We argue that the nature of the main mode of innovation has implications for the most important sources of sectoral innovation failure in each category, and consequently, for the most effective form of public support for private innovation.

III. Innovating input suppliers

In intermediate good industries, the predominant form of innovation is the development of higher quality products that will be used as inputs in vertically related industries. The software industry and equipment-producing industries are examples. In such sectors (Dosi, 1988, p. 1149)

opportunities for innovation are generally abundant, but are likely to be exploited through "informal" activities of design improvement... Idiosyncratic and cumulative skills make for a relatively high appropriability of innovation.

High appropriability means there are large private incentives to innovate in such sectors. However, the idiosyncratic and cumulative nature of the skills involved means that financial market transaction costs of the kind emphasized by Oliver Williamson (rooted in imperfect and impacted information combined with moral hazard) will be high and will make the cost of capital facing new, small innovating firms differentially high, if indeed capital in adequate amounts can be obtained at all.

Innovative inputs will in some cases have a generic character, meaning that they can be used in many industries with relatively modest additional development. For such technologies complete appropriability of the returns from innovation is difficult. From a social perspective, there will be insufficient private capital for 
development of generically applicable innovative inputs even in the absence of transaction costs in financial markets.

In these circumstances, whether appropriability is high or low, an effective mechanism for public support should make capital funding available to SMEs, including start-up firms. ${ }^{9}$ This will allow innovative new firms to bring socially useful products to market. The lowering of entry barriers implied by such a policy would maintain competitive pressure on larger incumbent firms, inducing them to continue their own innovative activities.

Because governments typically have a poor record of identifying ultimately successful lines of technological development in advance, public support for innovating SMEs should not take the form of direct grants. ${ }^{10}$ Nor should it take the form of government debt or direct equity financing.

Rather, government should limit its role to setting up market infrastructure and creating an environment conducive to entrepreneurship. But new, technologically intensive firms would not receive sufficient capital in such a setup, and such capital constraints would limit R\&D investment especially for SMEs. ${ }^{11}$ The question, then, is

\footnotetext{
${ }^{9}$ Such support is especially warranted early in an industry life cycle (Gemser et al., 1996).

${ }^{10}$ Certainly there can be exceptions, such as when the U.S. Department of Defense (DoD) awards Small Business Innovation Research Awards in areas where it has procurement interests. Often the technologies developed by the SMEs in conjunction with those awards will have commercial, non-military applications as well, but the research at the outset is focused on the mission of a DoD agency. As Nelson (1982, pp. 460-461) observes, with "government procurement-oriented R\&D . . . a government agency spends to further its own reasonably well defined purposes, and its evaluation of the technology emanating from $R \& D$ determines whether the new technology will be used or not." Given "a recognized public interest in certain kinds of advances" along with "a government agency [that] stands ready to see that the fruits of R\&D are employed" (Nelson, 1982, p. 461), direct government grants to the private sector can work well.

11 See Lerner (1996), Hall (1992), Hao and Jaffe (1993), Himmelberg and Petersen (1994), Wallsten (1997), and Hubbard (1998).
} 
how to deliver additional public funding to provide sufficient investment funds in a risky environment without losing the monitoring ability of private venture capital firms and without trying to implement such monitoring with clumsy and costly contracts or administrative mechanisms.

A contingent valuation method in which private agents bid for the right to obtain public funds for use in financing innovation projects would establish the desired incentives for the private sector to choose the best innovators and for such innovators to carry out the appropriate amounts of investment at the least cost to the public while avoiding opportunistic behavior by either the public or the private partner. ${ }^{12}$

Such a scheme would involve a hybrid bidding mechanism that combines an up-front bid, a periodic payment bid, and finally a royalty bid. ${ }^{13}$ Private venture capital companies would bid for public funds that would be used to fund innovative projects, rather than having the government accept bids directly from companies carrying out R\&D.

The government would announce that it would provide an up-front payment $F$ to support $\mathrm{R} \& \mathrm{D}$ investment to be funded by the winning bidders in an auction to determine the private venture capital firms that would be the direct recipients of funds. Further, the government would pledge to provide a periodic flow of funds $c$ throughout the funding cycle to support the flow costs of R\&D. ${ }^{14}$

Bidders then bid for the right to obtain funding by submitting a three-part bid:

\footnotetext{
12 For a detailed discussion of the proposed mechanism, see Martin and Scott (1999).

13 See McAfee and McMillan (1987) for a review of bidding mechanisms, as well as Hansen (1985) and Samuelson (1983, 1986). See Goel (1998) for a model of auctions of $R \& D$ contracts by a non-profit principal where bidders are potential developers.

14 Note that the fixed cost $F$ and the flow cost $c$ correspond to the typical abstraction of the structure of costs for R\&D investment projects (Lee and Wilde, 1980).
} 
- first a bid for how much the private firm will pay the government up-front;

- second a bid on the periodic flow payment during the life of the R\&D project;

- finally a bid on the royalty rate that would be paid to the government on publicly supported innovations licensed to the private sector.

There are nontrivial choices to be made about the exact nature of the auction. Apart from the usual choices for auctions in general, there would be choices specific to the institutional use of auctions to determine private firms to receive publicly supported projects. For example, institutional arrangements must be designed to insure that the government's payments of $F$ and $c$ go where they are intended, for the support of innovation; bidding would be limited to firms that can establish themselves as bona fide competent venture capitalists. ${ }^{15}$

We do not develop full details of the auction mechanism here, but present the basic idea and observe that the three-part bidding mechanism we propose has the potential for effectively addressing innovation market failure that arises from transaction costs in financial markets or from incomplete appropriation of the returns from innovation.

- First, by way of a well-designed auction, partners that can demonstrate their likely viability will be chosen to receive public funds. Intuitively, the firms that believe they can produce the best results at the least cost will gain more value from winning the bid to be the private partner in the public-private partnership; therefore, they will offer higher bids and receive public support.

- Second, the government's investment cost will be minimized. Intuitively, since that cost is the present value of (1) the up-front investment $F$ minus the up-front bid and (2) the flow cost $c$ minus the periodic flow payment, the firm with the best capabilities for identifying innovative firms to receive venture capital support at lowest costs will submit the highest bids for the up-front payment and the periodic flow payment. The government's net costs are reduced further by the royalty payments it will receive. Those royalty payments, however, serve other specific roles in the mechanism design.

15 This aspect of the implementation of the proposed bidding scheme is essential. Procedures have been developed to satisfy similar requirements in the past - for example, screening of bidders in U.S. airwaves auctions - and such screening mechanisms could be applied to venture capital funding auctions. 
- Third, the royalty payments are the contingent payment option that mitigate the effects of uncertainty by tying the private firm's actual payment to the government to the realized performance of the $R \& D$ investments that it supports. The contingent payment mechanism then increases the willingness of private firms to bid, increases the winning bids, and reduces the expected cost to the government. Greater uncertainty about value implies a lower expected price at the auction. Using royalty bidding as a type of contingent pricing mechanism gets around this problem, in effect giving ex post pricing; without contingency pricing less would be bid because no one would know what to pay for public funds. However, as we note below, with royalties there is an agency problem that changes the way the winning bidders will exploit a realized innovation, and we address this issue below.

- Fourth, the royalty payments effectively give the government an equity stake in the portfolio of projects supported by the venture capital firms that receive support, and reduce the likelihood of opportunistic behavior on the part of the government. Suppose a venture capital firm has in its portfolio projects for which public support - not only funds but also the energy and talents of the government's employees such as those in public laboratories and technology policy departments - will be needed for many fiscal years. The government's equity position in the project is a way to ensure the credibility of public support throughout those early investment years despite changes in administration or public sentiment. The equity position will make it credible that the government will not abandon such projects in midstream, and thus make private participation and investment more attractive.

- Fifth, the likelihood of opportunistic behavior by the private investors is reduced because the private firm or firms invest with up front and periodic payments, and good faith behavior would be required to keep the flow payment of public funds $c$ coming and keep the prospect of the private share of the project's earnings alive.

- Royalties to the government in return for use of the technology must be low enough so that the problem of reduced incentives for the private firm to promote the innovation does not outweigh the gains because the royalty mechanism mitigates risks and ensures continued public support.

The proposed mechanism, broadly, is that venture capital firms bid for supplemental financial resources from the public sector using a three part bid reflecting the up-front, fixed costs of $R \& D$ projects to be included in the firms' investment portfolios, the flow costs of such projects, and the stream of profits from the resulting innovations. Government wants innovators that are most likely to be successful to receive support, and it wants to promote private innovation in a costeffective way. The three-part bidding mechanism that we propose would provide the desired properties. By having private venture-capital companies bid for public funds, as opposed to the early-stage companies actually seeking to develop new products or 
processes, the proposed aid mechanism will take advantage of the expertise and supervisory ability that resides in the venture capital segment of financial markets.

IV. Innovating Input Users

Dual to the category of sectors where innovation takes the form of developing higher-quality inputs that are used in vertically related upstream industries is the category of firms in the customer industries that innovate by adapting products and processes developed in downstream industries to their own commercial needs.

There is a hand-in-glove connection between the development of innovative inputs in one industry and their application in others. In some cases, this may induce vertical integration or semi-integration, as manufacturers involve suppliers in an intimate way in the preparation of the final product. ${ }^{16}$

But sectoral innovation failure can arise both in the development of higherquality inputs and in the utilization of those inputs; public support for private innovation should be allocated so that the marginal social return to public funds is the same in both sectors. As the source of innovation failure is different in the two types of industries, the framework for providing public support should also be different.

One example comes from north central Italy (Best, 1990, p. 218):

The strength of the Third Italy is in the flexibility and innovation that come from decentralized and autonomous design capabilities. But competing on the basis of product design, quality, or customization depends upon integrating marketing capabilities and competitor analysis with production flexibility which, in turn, depends upon staying abreast of technological developments. Here again small firms are faced with the need to undertake activities characterized by substantial economies of scale.

Agricultural sectors share many of these characteristics: small operating units, not in rivalrous competition (Nelson, 1982, p. 466), able to benefit from adopting 
state-of-the-art techniques, but ill-able to afford the expense of keeping abreast of such techniques, and able to internalize only a fraction of the overall benefits that flow from keeping the sector as a whole on the technological frontier.

Public support for innovation in such sectors can take the form of extension services that serve as an open technical repository to which private firms can turn for the solution of specific problems. Such a system has been used in U.S. agriculture since 1862 (Adams and Martin, 1986; Nelson and Rosenberg, 1993, p. 12; Mowery and Rosenberg, 1993, p. 37).

Burton and Hansen (1993) discuss a functionally equivalent German mechanism to support industrial innovation: the Fraunhofer Gesellschaften, which (1993, p. 39)

conduct applied research for industry on a contract basis, using the facilities and personnel of regional polytechnics or technical universities.

The cooperative industrial research associations are organized by industry and identify the research needs of SMEs and actually carry out the research themselves or hire others to perform contract research. They identify five specific advantages of such cooperative research associations, which (p. 39)

- encourage industrially relevant research;

- promote the exchange of information between industrial and academic communities;

- assist commercialization and marketing;

- socialize university students with respect to commercial application of technology;

- promote the diffusion of research.

16 See, for example, Brown and Swoboda (1998). We are indebted to William L. Baldwin for this reference. 
Such associations will be of greatest assistance to SMEs, and the benefits seem mostly to be related to knowledge dissemination rather than increasing the private appropriability of knowledge.

Public support for innovation in sectors where technological progress takes the form of application of higher-quality inputs that are developed in supplying sectors should take the form of networks of public institutions that serve as repositories of information about developments on the technological frontier and that promote diffusion of innovations by transmitting such information, in usable form, to using sectors.

\section{Complex Systems Innovation}

Only a few sectors, although it is possible to argue that they are vital ones, fall in this category. Firms in these sectors are typically large in an absolute sense, and well able to maintain their own firm-specific pools of technical competence. Sectoral innovation failure arises because the $R \& D$ projects involved carry a cost that is proportionally as large or larger than the absolute size of innovating firms, and because of the nature of the risk associated with failure to stay on the technological frontier.

The risk in question is the risk of extinction if a firm is not in the first round of innovators - drastic innovation, in the vocabulary of the theoretical literature because a steep learning curve implies that second-movers fall rapidly behind. Society is concerned simply that the innovation occur; an individual firm is concerned that it be the winner of the innovation race, or more precisely, that it not be among the losers. The high set-up cost and drastic risk associated with innovation in such sectors combine to limit expected private gains to such a point that the market will not undertake many socially desirable projects. 
One part of policy in this area should be adoption of a competition policy that permits $\mathrm{R} \& \mathrm{D}$ cooperation. The evidence suggests that a general relaxation of competition policy vis-à-vis $R \& D$ cooperation will not have much effect on the level of private investment in innovation, since the fear of competition policy prosecution does not appear to be a factor that discourages individual or joint R\&D. In addition, firms will typically be risk-averse about divulging proprietary information.

Such an attitude was, for example, a characteristic of Japan's VLSI (Very Large Scale Integrated circuit) Project, in which companies' attitudes toward proprietary knowledge dictated the nature of the goals that could realistically be set for joint research (Sigurdson, 1986, pp. 45-6):

In selecting the themes of the research project it soon became evident that it would only be possible to carry out research ... which was fundamental in nature and which was of great common interest. Thus it was necessary to find out the common interest in order to make cooperation possible. Then, there would be no introduction of company know-how and that problem would disappear.

Policy should also be open to the possibility of direct subsidies, at least early in the life of cooperative activity. ${ }^{17}$ A condition of such subsidies should be acceptance of arrangements to diffuse knowledge generated by the joint venture to all comers on reasonable terms (perhaps after a certain delay). ${ }^{18} 19$ Learning-by-doing

\footnotetext{
17 What Dosi (1988) calls technological trajectories are likely to be fairly well defined in these sectors, and the problems associated with government selection of projects to back are less likely to arise than for sectors populated by innovating input suppliers.

18 One of Nelson's (1982, p. 465) reasons for urging public support of basic and generic research is that such support encourages treatment of research results as public goods. Our suggestion that a condition for direct $R \& D$ subsidies should be a willingness to diffuse research results is made in the belief that such treatment is desirable from a social point of view.

19 Martin (1998b) shows that in advance of discovery neither society nor firms will prefer complete appropriability of the rents that flow from innovation. Firms benefit from limited appropriability, in an expected value sense, because before discovery there is some probability that a firm will not be the first to make a discovery, and hence will benefit from prior discovery by a rival. Society benefits from limited
} 
advantages will normally allow incumbents to profit from exploiting an innovation; the availability of the innovation to outsiders at reasonable cost will prevent firstinnovators from extracting excessive economic profits and ensure a satisfactory level of consumer benefits.

Innovation market failure may also arise in these sectors when innovation involves the development of common standards for infrastructure technology. Such innovations involve network externalities and carry a substantial risk if a firm enters into a technological trajectory (Dosi, 1988) that ultimately fails to be selected as the market standard. Public bridging institutions investing in infrastructure technology would fill an essential gap in such cases. In the United States, the National Institute of Standards and Technology provides such investments.

VI. High Science-Content Technology Industries

Where innovation relies on a technology base with a high science content, there is also a need for bridging institutions. Firms in such sectors will often be large in an absolute sense, and will typically maintain their own formal R\&D laboratories. The role of bridging institutions in this case is to facilitate diffusion of advances in basic research from academic research operations to the private sector. One such sector is biotechnology, where (Mowery and Rosenberg, 1993, p. 70):

[r]ecombinant DNA and genetic engineering techniques in many ways represent radical scientific breakthroughs that are being transferred to industry and reduced to practice.

appropriability because it gives improved post-discovery product-market performance. After the fact, the successful innovators will prefer complete appropriability. 
Another is pharmaceuticals. For example, in his review of the development of beta blockers by Swedish pharmaceutical companies, Stankiewicz (1997, p. 109) writes that success ${ }^{20}$

depended on the ability of ... companies to link up the clinical and chemical competence into a coherent whole by relying on basic biological and pharmacological knowledge.

Close formal and informal connections with university researchers (including the physical location of some company research operations near universities) were important factors in making these linkages possible (Stankiewicz, 1997, p. 113, p. 130).

A common characteristic of technological progress in high-technological areas is the firms in the private sector are able to develop and appropriate the returns from commercialization of fundamental breakthroughs. Indeed, commercial application of such advances will typically best be carried out at private laboratories, which will be able to use information from marketing and distribution channels to direct development in the most effective direction.

For high technology industries, public support should promote the basic research that generates the foundation for commercialization. Mowery's (1989, p. 157) remarks on the advisable structure for public support of high-temperature superconductors are generally applicable to high science-content sectors:

The case for public support (e.g., through matching grants) of universityindustry research collaborations ... seems strong. Rather than targeting specific applications, however, public policy should attempt to broaden and enrich the R\&D network and the knowledge base on which individual firms can draw in developing ... applications.

Bridging institutions here could be university-industry research parks or government laboratories such as those operated in the U.S. by the National Institute of

\footnotetext{
${ }^{20}$ See also Eliasson and Eliasson (1997).
} 
Standards and Technology. ${ }^{21}$ Their role should be to provide a common forum for the diverse fields of knowledge that combine to generate progress in high science-content sectors, to promote basic research and make the results of such research available to the private sector for commercial development on terms that assure workable competition in the product market.

VII. Conclusions

One of the propositions that industrial economics has made its own in the last 20 years is that general analytical frameworks are generally inappropriate. Industries differ enough and in sufficiently important aspects that these differences must be taken into account in explaining market performance. This is true for technological performance as well as product market performance in a static sense. With respect to the appropriate institutional framework for public support to investment in innovation, factors to be taken into account are

- whether innovation is incremental in nature or takes the form of discrete, fundamental breakthroughs;

- the extent to which patents or other mechanisms allow innovators to appropriate a sufficient share of the profits that result from successful innovation;

- the degree of product-market rivalry;

- the importance of learning-by-doing (if present, $R \& D$ is a necessary ticket to enter the product market).

The prevalence of innovation market failure and underinvestment in technology implies the need to establish a long-term institutional framework for the support of basic research, generic-enabling research, and commercialization. The

${ }^{21}$ See Tassey (1997), Link and Scott (1998a), Scott (1998a); and for a review of the expanding role of universities in US innovation, Mowery (1998). 
extent to which support should be directed to each area will vary with the sources of sectoral innovation market failure.

In this regard, simple distinctions, as for example between "high tech" and "low tech" industries, may not be sufficient: agriculture would generally be thought of as "low tech," yet cumulative technological advance in US agriculture has been great, and the potential payoff to such advances in LDCs may well be enormous. ${ }^{22}$

We offer a menu that matches institutional support frameworks and four broad innovation modes:

- development of innovative inputs - public support for venture capital markets;

- application of innovative inputs - low-tech bridging institutions to facilitate technology transfer;

- development of complex systems - R\&D cooperation, subsidies, support for development of infrastructure technology;

- high science-content technology — high-tech bridging institutions.

For the first category, we have sketched a prototype three-part bidding mechanism and explained why it can potentially provide the desired traits for delivering the public funds to support private-sector innovation. Such a mechanism would address sources of innovation market failure that arise in financial markets. By having private venture-capital companies bid for the contract, the aid mechanism would incorporate private venture-capital-market supervision of investments made by early-stage firms or joint ventures.

22 With universities and publicly funded research stations focused on agricultural $\mathrm{R} \& \mathrm{D}$, and with the large equipment and materials agricultural businesses as well as the farms themselves, the agricultural sector is well-endowed with important and evolving technology - even exotic high-technology such as genetic manipulation of plant and animal materials. 
In the second and fourth categories, institutional support should take the form of bridging institutions. Where innovation takes the form of applying inputs developed in supplying industries, extension services will facilitate technology transfer. Where innovation requires the application of knowledge and techniques on the frontier of knowledge, it is high-tech bridging institutions (university-industry commercial parks and the like) that are called for.

In sectors where innovation takes the form of development of high-cost, high risk complex systems, $R \& D$ subsidies may be called for, and public policy should take a relaxed attitude toward $R \& D$ cooperation (while promoting open licensing of resulting innovations).

Policymakers should of course be aware of the risk of "government failure" as well as of sectoral innovation failure. But the strong evidence of underinvestment in technological advance justifies public action to support private innovation, and the variations across sectors in the sources of innovation underinvestment indicate that the mechanisms to deliver that support should also vary across sectors. 


\section{References}

Adams, Walter and Martin, Stephen "Public support of innovative activity: lessons From U. S. industrial policy," in H. W. de Jong and W. G. Shepherd, editors, Mainstreams in Industrial Organization Dordrecht: Martinus Nijhoff, Publishers, 1986, pp. 413-39.

Anderson, Simon P., Goeree, Jacob K., and Holt, Charles A. "Rent seeking with bounded rationality: an analysis of the all-pay auction," Thomas Jefferson Center Discussion Paper 283, University of Virginia, February 1997.

Baker, Jonathan B. "Promoting innovation competition through the Aspen/Kodak rule," prepared remarks before The George Mason University Law Review Antitrust Symposium: the changing face of efficiency, 16 October 1998, forthcoming in the George Mason Law Review (available on-line at http://www.ftc.gov/speeches/other/mason1098.htm).

Baldwin, William L., and Scott, John T. Market Structure and Technological Change, in the series Fundamentals of Pure and Applied Economics, vol. 17. Chur; London; Paris; New York: Harwood Academic Publishers, 1987.

Best, Michael H. The New Competition. Cambridge, Massachusetts: Harvard University Press, 1990.

Brown, Warrem and Swoboda, Frank "Changes on the factory floor," Washington Post, 4 December 1998, p. D01.

Burton, Daniel F. and Hansen, Kathleen "German technological policy: incentive for industrial innovation," Challenge, Volume 36, Number 1, January-February 1993, pp. 37-47.

Dosi, Giovanni "Sources, procedures, and microeconomic effects of innovation," Journal of Economic Literature Volume 26, September 1988, pp. 1120-71.

Eliasson, Gunnar and Eliasson, Åsa "The pharmaceutical and biotechnological competence bloc and the development of Losec," in Carlsson, Bo, editor Technological Systems and Industrial Dynamics. Dordrecht: Kluwer Academic Publishers, 1997, pp. 139-168.

Fisher, F. M. and Temin, Peter, "Returns to scale in research and development," Journal of Political Economy Volume 81, 1973, pp. 56-70.

Fudenberg, Drew and Tirole, Jean "Understanding rent dissipation: on the use of game theory in industrial organization," American Economic Review Volume 77, Number 2, May 1987, pp. 176-83.

Galbraith, John Kenneth American Capitalism: The Concept of Countervailing Power. Boston: Houghton-Mifflin, 1952. 
Gemser, Gerda, Leenders, Mark A. A. M. and Wijnberg, Nachoem M. "The dynamics of inter-firm networks in the course of the industry life cycle: the role of appropriability," Technology Analysis \& Strategic Management Volume 8, Number 4, December 1996, pp. 439-53.

Goel, Rajeev K. “On contracting for uncertain R\&D,” mimeo, July 1998.

Hall, Bronwyn H. "Investment and research and development: does the source of financing matter?," Working Paper No. 92-194, 1992, Department of Economics, University of California at Berkeley.

Hansen, Robert G. "Auctions with contingent payments," The American Economic Review, Volume 74, no. 4 September 1985, pp. 862-865.

Hao, Kenneth Y. and Jaffe, Adam B. "Effect of liquidity on firms' R\&D spending," Economics of Innovation and New Technology Volume 2, 1993, pp. 275-282.

Himmelberg, Charles P. and Petersen, Bruce C. "R\&D and internal finance: a panel study of small firms in high-tech industries," Review of Economics and Statistics, Volume 76, 1994, pp. 38-51.

Hubbard, R. Glenn "Capital-market imperfections and investment," Journal of Economic Literature Volume 36, Number 1, March 1998, pp. 193-225.

Kamien, Morton I. and Schwartz, Nancy L. Market Structure and Innovation. Cambridge: Cambridge University Press, 1982.

Kohn, Meir and Scott, John T. "Scale economies in research and development," Journal of Industrial Economics Volume 30, Number 3, March 1982, pp. 239249.

Lee, Tom and Wilde, Louis L. "Market structure and innovation: a reformulation," Quarterly Journal of Economics Volume 94, Number 2, March 1980, pp. 429436.

Lerner, Josh "The government as venture capitalist: the long-run impact of the SBIR program,” NBER Working Paper 5753, September 1996.

Link, Albert N. and Scott, John T. Public Accountability: Evaluating TechnologyBased Public Institutions. Boston: Kluwer Academic Publishers, 1998a.

- Overcoming Market Failure: A Case Study of the ATP Focused Program on Technologies for the Integration of Manufacturing Applications (TIMA). Report Submitted to the Advanced Technology Program, $1998 \mathrm{~b}$.

Martin, Stephen "Product market competition policy and technological performance," December 1998a

— “Spillovers, appropriability and R\&D," December 1998 b. 
Martin, Stephen and Scott, John T. Financing and Leveraging Public/Private Partnerships, a report on financial engineering for technology and innovation policy prepared for the Working Group on Technology and Innovation Policy, Division of Science and Technology, OECD, January 30, 1998 (available online at url http://www.econ.ku.dk/CIE/flppp.pdf.)

— "Financial market transaction costs and R\&D policy," mimeo, in process, 1999.

McAfee, R. Preston, and McMillan, John "Auctions and bidding," The Journal of Economic Literature Volume 25, No. 2, June 1987, pp. 699-738.

Mowery, David C. "Collaborative research and high-temperature superconductivity," in Link, Albert N. and Tassey, editors. Gregory Cooperative Research and Development: the Industry-University-Government Relationship. Boston: Kluwer Academic Publishers, 1989, pp. 145-5.

- "The changing structure of the US national innovation system: implications for international conflict and cooperation in R\&D policy," Research Policy Volume 27, 1998, pp. 639-54.

Mowery, David C. and Rosenberg, Nathan "The U.S. national innovation system," in Nelson, Richard R., editor. National Innovation Systems. Oxford: Oxford University Press, 1993.

Nelson, Richard R. "Government stimulus of technological progress: lessons from American history," in Nelson, Richard R., editor Government and Technical Progress. New York: Pergamon Press, 1982, pp. 451-82.

Nelson, Richard R. and Rosenberg, Nathan "Technical innovation and national systems," in Nelson, Richard R., editor. National Innovation Systems. Oxford: Oxford University Press, 1993.

Pavitt, Keith "Patterns of technical change: towards a taxonomy and a theory," Research Policy Volume 13, Number 6, 1984, pp. 343-73.

Samuelson, William F. "Competitive bidding in defense contracting," in R. Engelbrecht-Wiggins et al., editors, Auctions, Bidding, and Contracting: Uses and Theory. New York University Press, 1983.

— "Bidding for contracts," Management Science, volume 32, no. 12 December 1986, pp. 1533-1550.

Schumpeter, Joseph A. The Theory of Economic Development. Cambridge, Massachusetts: Harvard University Press, 1961 [reprint of 1934 edition] .

- Capitalism, Socialism and Democracy. New York: Harper \& Row, 1942; Colophon edition, 1975. 
Scott, John T. "The service sector's acquisition and development of information technology," Journal of Technology Transfer, forthcoming, 1998a.

- "The hurdle-lowering auction: a mechanism for financing and leveraging public/private partnerships," STI Review, No. 23, Paris, OECD, 1998 b.

Sigurdson, Jon Industry and State Partnership in Japan: the Very Large Scale Integrated (VLSI) Circuit Project. Lund: Swedish Research Policy Institute, University of Lund, 1986.

Stankiewicz, Rikard "The development of beta blockers at Astra-Hässle and the technological system of the Swedish pharmaceutical industry," in Carlsson, Bo, editor Technological Systems and Industrial Dynamics. Dordrecht: Kluwer Academic Publishers, 1997, pp. 93-137.

Tassey, Gregory The Economics of R\&D Policy. Westport, Connecticut; London: Quorum Books, 1997.

Wallsten, Scott "Can government-industry R\&D Programs Increase Private R\&D? the case of the small business innovation research program," manuscript, November 1997, Stanford University. 